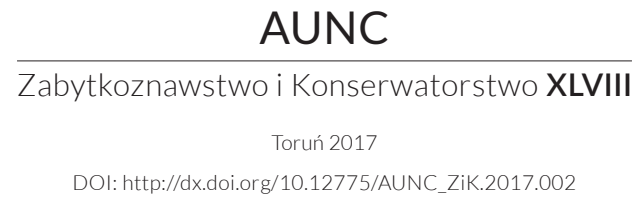

\title{
Badania nad średniowiecznymi materiałami budowlanymi z zamku w Radzyniu Chełmińskim*
}

\author{
KAROLINA WITKOWSKA \\ Zakład Konserwacji Elementów i Detali Architektonicznych, \\ Wydział Sztuk Pięknych, UMK w Toruniu \\ e-mail: karolina.witkowska@umk.pl
}

Keywords: masonry brick, bedding mortar, Radzyń Chełmiński / Rehden - teutonic castle, applied mineralogy, thermal analysis (DSC-TG)

Słowa kluczowe: cegła formatowa, zaprawa murarska, Radzyń Chełmiński - zamek krzyżacki, mineralogia stosowana, analiza termiczna (DSC-TG)

\begin{abstract}
Research on medieval building materials from Radzyń Chełmiński castle

The research concerns technology aspects of chosen historic materials: masonry bricks and bedding mortars. Samples of materials mentioned above come from Radzyń Chełmiński / Rehden Teutonic castle. Following bricks' and mortars' properties were determined: composition, structure and texture. Above-mentioned characterization is a result of examinations carried out in accordance with following methodology:

Przedstawione badania zostały sfinansowane przez Narodowe Centrum Nauki (UMO-2014/ 13/N/HS2/02879). Autorka dziękuje prof. dr hab. Jadwidze W. Łukaszewicz (Zakład Konserwacji Elementów i Detali Architektonicznych, UMK w Toruniu) za cenne uwagi merytoryczne, dr. Wojciechowi Bartzowi (Instytut Nauk Geologicznych, Uniwersytet Wrocławski) za wykonanie analiz petrograficznych i ich interpretację oraz mgr Wiesławie Topolskiej (Zakład Konserwacji Elementów i Detali Architektonicznych, UMK w Toruniu) za przeprowadzenie analizy termicznej i wykonanie obliczeń.
\end{abstract}


determination of composition of masonry materials by thermal analysis (DSC-TG) and petrographic analysis. To properly recognize the materials quantitative analysis of were carried out. It was found that the examined materials have similar composition but there are difference in proportions of components. The results show that the majority of mortar samples presents intermediate hydraulic character. Research results can be a contribution for a complex studies of similar groups of architectonic objects and facilitate to compare polish and European medieval masonry workshops.

\begin{abstract}
Abstrakt
Celem podjętych badań jest lepsze poznanie średniowiecznego warsztatu budowlanego działającego na zamku w Radzyniu Chełmińskim, a konkretnie użytych do wzniesienia warowni podstawowych materiałów budowlanych - cegieł formatowych i zapraw murarskich. Do określenia składu i budowy, struktury oraz tekstury badanych materiałów zastosowano analizę makroskopową i mikroskopową, wykonano badania petrograficzne, a dla zapraw dodatkowo analizę termiczną (DSC-TG) i analizę chemiczną. Stwierdzono, że badane materiały mają podobną budowę mineralogiczną, lecz nieco różnią się udziałem poszczególnych składników. Ponadto wykazano, że spoiwo wapienne większości zapraw zawiera pojedyncze fazy hydrauliczne. Wyniki badań mogą posłużyć jako przyczynek do szerzej zakrojonych studiów materiałoznawczych nad średniowiecznym budownictwem zakonu krzyżackiego i w konsekwencji umożliwić porównanie krzyżackiego warsztatu budowlanego z technologią stosowaną na terenie Polski i Europy.
\end{abstract}

\title{
Wstęp
}

Pierwsza warownia krzyżacka powstała w Radzyniu w 1234 roku z zastosowaniem techniki drewniano - ziemnej ${ }^{1}$. W związku z brakiem jej śladów w obrębie zamku murowanego, można przypuszczać, że znajdowała się w miejscu wczesnośredniowiecznego grodu położonego na południowy wschód od obecnego założenia ${ }^{2}$. Wkrótce potem, przed październikiem 1251 r., powstało tu komturstwo ${ }^{3}$.

Pod budowę warowni murowanej wybrano zupełnie nową lokalizację porzucając wcześniejsze założenie. Jak dowodzą najnowsze badania, radzyński

1 Bogusz Wasik, "Początki krzyżackich zamków na ziemi chełmińskiej. Pierwsze warownie i obiekty murowane”, Archaeologia Historica Polona, 24 (2016): 234.

2 Bogusz Wasik, “Zamek w Radzyniu Chełmińskim: technika i etapy budowy siedziby krzyżackich komturów i konwentu”, Ochrona Zabytków 68, nr 1 (2015): 167, 175-177.

3 Janusz Tandecki, “Podziały administracyjne państwa zakonnego w Prusach”, w Zakon krzyżacki w Prusach i Inflantach. Podziały administracyjne i kościelne w XIII-XIV wieku, red. Roman Czaja, Andrzej Radzimiński (Toruń, Wydawnictwo Naukowe Uniwersytetu Mikołaja Kopernika, 2013), 35. 
zamek powstał w dwóch fazach ${ }^{4}$, prawdopodobnie w stosunkowo krótkim czasie: od 10 do 20 lat ${ }^{5}$. Najpierw wzniesiono dom konwentu (bez wieży) ${ }^{6}$; jego budowa trwała od początku lub końca drugiego dziesięciolecia XIV wieku do około 1330-1340 roku lub połowy wieku (I faza) ${ }^{7}$. Prace budowlane kontynuowano od połowy do końca stulecia, kiedy powstały wieża, parcham i przedzamcze (II faza) $)^{8}$.

Budulecradzyńskiegozamku,podobniejakwiększości warowni krzyżackich na terenie Prus, stanowi głównie cegła formatowa i zaprawa murarska. W obiekcie tym zastosowano ponadto ceramikę specjalną: reliefowe płytki oraz kształtki (w tym glazurowane). Oprócz materiałów ceramicznych w zachowanych do dziś murach zamku odnaleźć można tzw. kamień polny użyty do wykonania fundamentów oraz granit, wapień zbity i sztuczny kamień wapienny ${ }^{9}$ (detale architektoniczne).

Mury domu konwentu postawiono z cegieł o wymiarach: główka $14-15 \mathrm{~cm}$, wozówka 30-32 cm, wysokość 8-9,5 cm, stosując równolegle wątek wendyjski i gotycki ${ }^{10}$. Cegieł o podobnym rozmiarze użyto do budowy radzyńskie-

4 Bogusz Wasik, Budownictwo zamkowe ziemi chełmińskiej (od XIII do XV wieku) (Toruń: Wydawnictwo Naukowe Uniwersytetu Mikołaja Kopernika, 2016), 292, 299.

5 Marian Arszyński, “Z badań nad zamkiem pokrzyżackim w Radzynie”, Rocznik Grudziądzki 2 (1961): 69-70.

6 Wasik, “Zamek w Radzyniu”, 169.

7 Wasik, Budownictwo zamkowe, 299; Tomasz Torbus, Die Konventsburgen im Deutschordensland Preußen (München: R. Oldenbourg, 1998), 601; Tomasz Torbus, Zamki konwentualne państwa krzyżackiego w Prusach (Gdańsk: Fundacja Terytoria Książki : Słowo/Obraz Terytoria, 2014), 185; Za podobnym datowanie opowiadają się również inni badacze: (lata 13001330) Christofer Herrmann, Mittelalterliche Architektur im Preussenland: Untersuchungen zur Frage der Kunstlandschaft und -geographie (Petersberg, Olsztyn: Michael Imhof Verlag, 2007), 675, (1. poł. XIV wieku), Architektura gotycka w Polsce, t. 2, red. Teresa Mroczko i, Marian Arszyński (Warszawa: Instytut Sztuki PAN, 1995), 198, (około początku XIII wieku), Ireneusz Sławiński, “Z badań nad zamkami w Golubiu, Radzyniu i Brodnicy”, w Komunikaty na sesję naukowa poświęconą dziełom sztuki Pomorza zorganizowaną w 500-lecie pokoju toruńskiego (Toruń: s.n., 1966) 57.

8 Wasik, “Zamek w Radzyniu”, 169; Wasik, Budownictwo zamkowe, 299.

9 Zbigniew Brochwicz, “Zaprawa wapienna jako tworzywo elementów architektonicznych na przykładzie służek w kaplicy zamkowej w Radzyniu Chełmińskim”, AUNC. Zabytkoznawstwo i Konserwatorstwo 4 (1971): 127-139.

10 Przyjmuje się, że w ostatniej dekadzie XIII w. wątek wendyjski ustąpił miejsca wątkowi gotyckiemu (Torbus, Zamki konwentualne, 369), lecz analiza muru wykazała, że w I fazie budowy zamku radzyńskiego zastosowano równolegle oba wątki. Wielkość tego założenia wymagała zapewne zatrudnienia kilku ekip murarzy i stosowanie starszego sposobu murowania można tłumaczyć ich preferencjami. Por. Herrmann, Mittelalterliche Architektur, 112. Do budowy wieży, parchamu i przedzamcza użyto większej cegły, o wymiarach $15-16 \mathrm{~cm} \times$ 31-33 cm × 8-9,5 cm; Wasik, "Zamek w Radzyniu”, 169. 


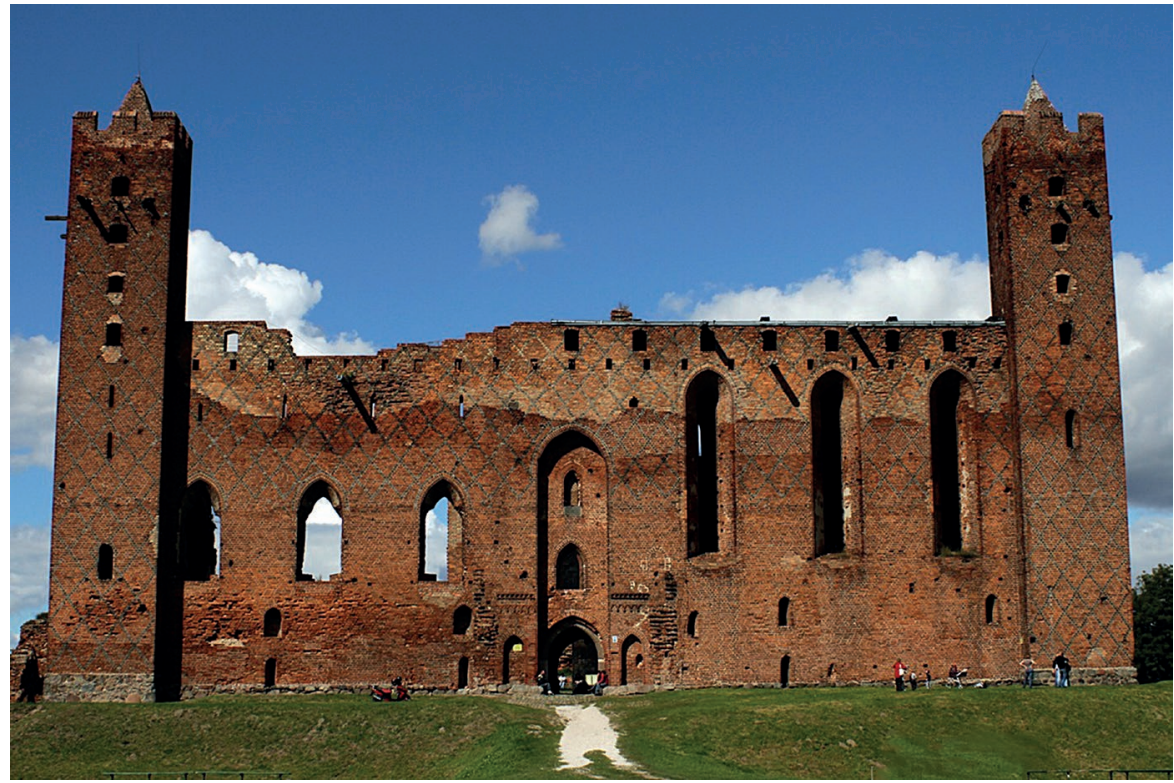

Fot. 1. Zamek w Radzyniu Chełmińskim. Widok na skrzydło południowe domu konwentu. Fot. Karolina Witkowska

go kościoła parafialnego ${ }^{11}$. Można zatem założyć, że podstawową ceramikę budowlaną dla obu obiektów produkowała ta sama cegielnia, działająca zapewne w najbliższej okolicy, założona na potrzeby obsługi obu inwestycji ${ }^{12}$. Za takim wnioskiem przemawia również oddalenie Radzynia Chełmińskiego od większych ośrodków miejskich i dogodne usytuowanie na Wysoczyźnie Chełmińskiej, bogatej w złoża glin i piasków różnego pochodzenia. W bezpośrednim sąsiedztwie Radzynia zalegają osady czwartorzędowe, które mogły być eksploatowane w celu pozyskania surowców ${ }^{13}$ :

- namuły den dolinnych stanowiące drobnoziarniste osady mineralne (muły i piaski) oraz osady pochodzenia biogenicznego (torfy i gytie),

- glina lodowcowa (zwałowa) będąca niewysortowanym homogenicznym osadem złożonym z mieszaniny iłu, piasku, żwiru oraz głazów,

11 Wasik, Budownictwo zamkowe, 157.

12 Marian Arszyński, Organizacja i technika średniowiecznego budownictwa ceglanego w Prusach w kontekście europejskim (Malbork: Muzeum Zamkowe w Malborku, 2016), 46.

13 Internetowy Atlas Województwa Kujawsko-Pomorskiego: Mapa geologiczna utworów powierzchniowych 1:500 000, Dostęp 5 kwietnia 2017, http://atlas.kujawsko-pomorskie.pl/ maps/app/map\# 
- piaski oraz żwiry z glinami spływowymi moren czołowych,

- piaski oraz mułki kemów i tarasów kemowych.

Zaprawę murarską przygotowywano przy użycia spoiwa wapiennego z dodatkiem kruszywa - w Radzyniu, pozbawionym cieku wodnego, z pewnością kopalnego. Nie można definitywnie rozstrzygnąć, jakie było pochodzenie kamienia wapiennego wykorzystanego do produkcji wapna niezbędnego do budowy badanego zamku. Prawdopodobnie pozyskiwano go zbierając fragmenty skał pozostawionych w glinie zwałowej w wyniku uwalniania materiału skalnego z lodu. Tezę tę zdają się potwierdzać liczne wzmianki źródłowe, w których ułomki te nazywane są „wapieniem polnym” lub „wapieniem zbieranym" ${ }^{14}$.

Technologiczny aspekt problematyki podstawowych materiałów budowlanych stosowanych w budownictwie powstałym na terenie państwa zakonu krzyżackiego był dotychczas przedmiotem jedynie wstępnych badań ${ }^{15}$. Średniowieczne techniki murarskie, w tym sposób produkcji cegieł i spoiw oraz zapraw, a także organizację pracy przy projektowaniu, przygotowywaniu i realizacji inwestycji szeroko omawia Marian Arszyński ${ }^{16}$. Wyniki studiów nad techniką budowy i analizy materiału ceramicznego odnaleźć można również w publikacjach będących owocem badań archeologiczno-architektonicznych

14 Arszyński, Organizacja i technika, 121.

15 Badania porównawcze cegieł i zapraw z zamków krzyżackich w Malborku, Toruniu i Radzyniu Chełmińskim zob. Karolina Witkowska i Jadwiga W. Łukaszewicz, “Comparative Studies on Masonry Bricks and Bedding Mortars of the Fortress Masonry of the Teutonic Order State in Prussia: Malbork, Toruń and Radzyń Chełmiński Castles”, w Science and Art: A Future for Stone: Proceedings of the 13th International Congress on the Deterioration and Conservation of Stone, t. 1, red. John J. Hughes i Torsten Howind (Paisley: University of the West of Scotland Press, 2016), 621-629.

16 Marian Arszyński, “Warsztat budowlany w Prusach około 1400”, Biuletyn Historii Sztuki 29, nr 4 (1967): 582-583; Marian Arszyński, “Technika i organizacja budownictwa ceglanego w Prusach w końcu XIV w. i poł. XV w.”, Studia z Dziejów Rzemiosła i Przemysłu 9 (1970): 7-139; Marian Arszyński, Budownictwo warowne zakonu krzyżackiego w Prusach (1230-1454) (Toruń: Wydawnictwo Uniwersytetu Mikołaja Kopernika, 1995), 117-123, 151-170; Marian Arszyński, "Problematyka techniczna budownictwa średniowiecznego Polski północnej na przełomie XIV i XV w.”, Biuletyn Informacyjny PKZ 8(1968): 95-122; Marian Arszyński, "Stosunki między zakonem krzyżackim a społeczeństwem w świetle rozważań nad organizacją budowy kościołów parafialnych w Prusach”, w Zakon krzyżacki a społeczeństwo państwa w Prusach: zbiór studiów, red. Zenon H. Nowak (Toruń: Towarzystwo Naukowe, 1995), 165-184; Marian Arszyński, “Budownictwo”, w Zakon krzyżacki i jego państwo w Prusach: wybór tekstów źródłowych, red. Andrzej Radzimiński (Torun: Wydawnictwo Uniwersytetu Mikołaja Kopernika, 2005), 123-144; Arszyński, Organizacja i technika. 
wybranych zamków z terenu Prus ${ }^{17}$. Niestety, w szeroko zakrojonych badaniach prawie nie podejmuje się problematyki technologicznej materiałów. Jedynie w opracowaniu dotyczącym zamku w Grudziądzu podano wyniki analiz dwóch średniowiecznych zapraw ${ }^{18}$. Zagadnienie źródła pozyskiwania surowca do wyrobu ceramiki budowlanej rozpatrywał Sławomir Skibiński, który podjął próbę potwierdzenia, że do wyrobu cegieł z toruńskiego zamku wykorzystano złoża iłu plioceńskiego i na tej podstawie, ustalił, że cegły te wypalano w temperaturach $1000-1100^{\circ} \mathrm{C}^{19}$. Informacje na temat właściwości, budowy i składu cegieł oraz zapraw dotyczące pojedynczych zabytków znajdują się również w dokumentacjach konserwatorskich, są to jednak opracowania niepublikowane i w praktyce nie mają wpływu na stan wiedzy w omawianym zakresie. Podsumowując, w literaturze przedmiotu brakuje prac, które rozwiązują szczegółowe problemy architektury krzyżackiej w jej aspekcie technologicznym.

\section{Przedmiot badań}

Celem podjętych badań jest lepsze poznanie średniowiecznego warsztatu budowlanego działającego na zamku w Radzyniu Chełmińskim, a dokładniej określenie składu i budowy zastosowanych do wzniesienia warowni podstawowych materiałów budowlanych - cegieł formatowych i zapraw murarskich.

Analizowane próbki (6 cegieł i 8 zapraw) pobrane zostały z murów domu konwentu w następujących miejscach: Rdz1, Rdz2, Rdz2', Rdz3, Rdz4, Rdz 5 północna część skrzydła zachodniego ${ }^{20}$, Rdz6, Rdz7, Rdz 8 - zachodnia część skrzydła południowego, Rdz 9, Rdz10, Rdz11c, Rdz11z - północna część skrzydła wschodniego, Rdz 12 - wnętrze pierwszej od wschodu celi w ścianie kaplicy.

17 Zamek w Grudziądzu w świetle badań archeologiczno-architektonicznych: studia i materiały, red. Marcin Wiewióra (Toruń: Instytut Archeologii Uniwersytetu Mikołaja Kopernika; Grudziądz: Urząd Miejski, 2012); Zamek biskupów chełmińskich w Wąbrzeźnie w świetle badań archeologiczno-architektonicznych : studia i materiały, red. Marcin Wiewióra (Toruń: Wydawnictwo Naukowe Uniwersytetu Mikołaja Kopernika, 2014); Wasik, Budownictwo zamkowe.

18 Dorota Sobkowiak i Elżbieta Orłowska, “Analiza źródeł architektonicznych. Wyniki badań składu zapraw”, w Zamek w Grudziądzu, 157-158.

19 Sławomir Skibiński, "Przyczyny niszczenia cegieł zabytkowych murów obronnych Torunia oraz zamku krzyżackiego w Toruniu”, w Naukowe podstawy ochrony i konserwacji dzieł sztuki oraz zabytków kultury materialnej, red. Alicja Strzelczyk i Sławomir Skibiński (Toruń: Wydawnictwo Uniwersytetu Mikołaja Kopernika, 1998), 190-192.

20 Celowo nie określono funkcji pomieszczeń ze względu na brak jednoznacznych ustaleń. 


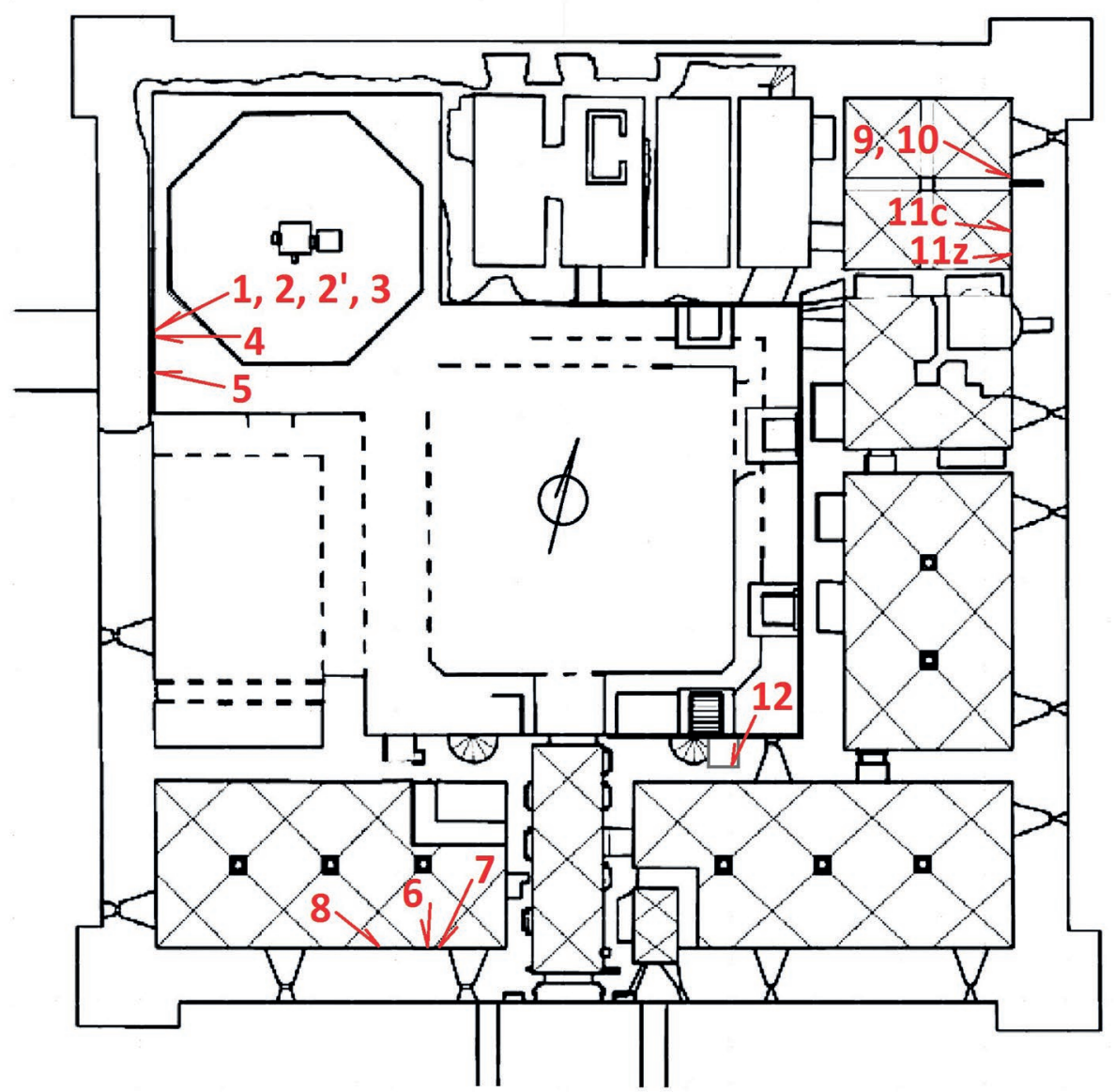

Ryc. 1. Zamek w Radzyniu Chełmińskim. Rzut domu konwentu z zaznaczonymi miejscami pobrania próbek. Oprac. Bogusz Wasik na podstawie pomiarów zamku wykonanych przez Ireneusza Sławińskiego i Romana Łopaciuka. Na rysunek naniesiono obrys pierwszej od wschodu celi w ścianie kaplicy (próbka Rdz12). Za: Bogusz Wasik, “Zamek w Radzyniu Chełmińskim: technika i etapy budowy siedziby krzyżackich komturów i konwentu”, Ochrona Zabytków 68, nr 1 (2015): 168 

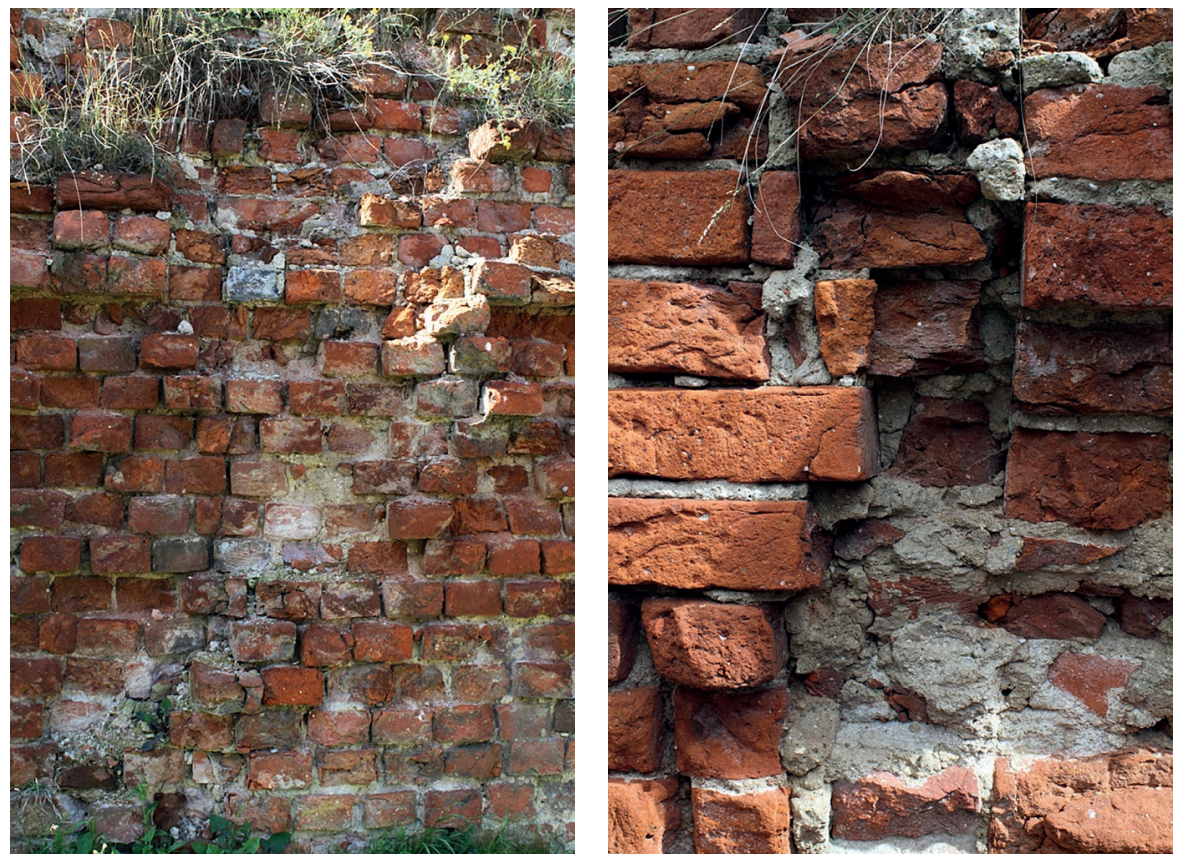

Fot. 2. Zamek w Radzyniu Chełmińskim. Fragmenty murów domu konwentu.

Fot. Karolina Witkowska

A - północna część skrzydła zachodniego, miejsce pobrania próbek Rdz 1, Rdz 2, Rdz 2', Rdz 3, Rdz 4, Rdz 5. B - północna część skrzydła wschodniego, miejsce pobrania próbek Rdz 9, Rdz 10

\section{Metodyka badań}

Poznanie właściwości pobranych próbek cegieł i zapraw wymagało przeprowadzenia szeregu analiz. Wszystkie materiały zostały poddane, w celu określenia ich struktury i tekstury, obserwacji pod mikroskopem stereoskopowym (Nikon SMZ800 z zakresem powiększenia 1x-6.3x). Obraz zarejestrowano przy użyciu aparatu cyfrowego Canon EOS 700D fotografując świeże przełamy próbek. Następnie z wybranych próbek obu materiałów przygotowano cienkie płytki i wykonano analizę mineralogiczno- petrograficzną za pomocą mikroskopu polaryzacyjnego Zeiss Axiolab ${ }^{21}$. Uziarnienie szkieletu ziarnowego oraz stosunki objętościowe minerałów wchodzących w skład badanych

21 Badania wykonał dr Wojciech Bartz z Instytutu Nauk Geologicznych Uniwersytetu Wrocławskiego. Wojciech Bartz, "Raport z badań mineralogiczno-petrograficznych: zaprawy i cegły z zamków w Toruniu i Radzyniu Chełmińskim” (raport, Wrocław 2016). 
próbek oszacowano za pomocą komputerowej analizy obrazu, stosując program JMicroVision v1.2.7. Dla zapraw wykonano ponadto analizę chemiczną przy użyciu 2M kwasu solnego, oznaczając ilość części nieroztwarzalnych w kwasie, oraz analizę termiczną (differentialscanningcalorimetry-thermogravimetry - DSC-TG ${ }^{22}$. Krzywe DSC-TG zarejestrowano przy użyciu analizatora termicznego PerkinElmer STA $6000 \mathrm{w}$ zakresie temperatur $30-950^{\circ} \mathrm{C}$ z szybkością przyrostu temperatury $10^{\circ} \mathrm{C} / \mathrm{min}$. Widma DSC-TG przeanalizowano by oznaczyć ubytek masy w zakresach temperatur $<120^{\circ} \mathrm{C}, 12-200^{\circ} \mathrm{C}$, $200-600^{\circ} \mathrm{C},>600^{\circ} \mathrm{C}^{23}$, a także procentową zawartość węglanu wapnia w temperaturze powyżej $560^{\circ} \mathrm{C}$.

\section{Dyskusja wyników}

\section{Zaprawy}

Na podstawie analizy makroskopowej i mikroskopowej oraz badań petrograficznych (tab. 1) stwierdzono, że badana grupa zapraw jest bardzo jednorodna. Ich kolor określić można jako szarobeżowy (Rdz 1, Rdz 2, Rdz 2', Rdz 11z) i szarobeżowy o ugrowym odcieniu (Rdz 6, Rdz 8, Rdz 10, Rdz 12). Wszystkie próbki cechują się bezładną teksturą i podobną strukturą (dominuje psamitowa, częściowo aleurytowa i psefitowa), a ich spoiwo ma najczęściej charakter porowy, miejscami bazalny i kontaktowy (fot. 3).

Kruszywo, o zbliżonym składzie, zawiera przede wszystkim piasek kwarcowy z dodatkiem fragmentów skał (reprezentowanych głównie przez granitoidy) i nielicznych skaleni. Rzadziej w składzie szkieletu ziarnowego można zaobserwować okruchy skał osadowych w postaci ziaren skał krzemionkowych (np. krzemienie.), piaskowca, a także fragmenty wapieni biogenicznych (biomikryty), w tym wapienie zapiaszczone.

Największe fragmenty skał zaobserwowano w próbkach Rdz 1, Rdz 2', Rdz 6, Rdz 8 (13-15 mm), w pozostałych nie przekraczają one $9 \mathrm{~mm}$. Szkielet ziarnowy uzupełniany jest przez liczne składniki akcesoryczne. Są to przede wszystkim ziarna minerałów nieprzezroczystych: glaukonit, muskowit, am-

22 Analiza chemiczna została wykonana przez autorkę artykułu. Analizę termiczną wraz z obliczeniami przeprowadziła mgr Wiesława Topolska.

23 Antonia Moropoulou, Asterios Bakolas i Katerina Bisbikou, "Characterization of Ancient, Byzantine and Later Historic Mortars by Thermal and X-ray Diffraction Techniques”, Thermochimica Acta 269/270 (1995): 779-795; Antonia Moropoulou, Asterios Bakolas i Katerina Bisbikou, "Investigation of the Technology of Historic Mortars", Journal of Cultural Heritage 1, no. 1 (2000): 45-58. 
Rdz 6
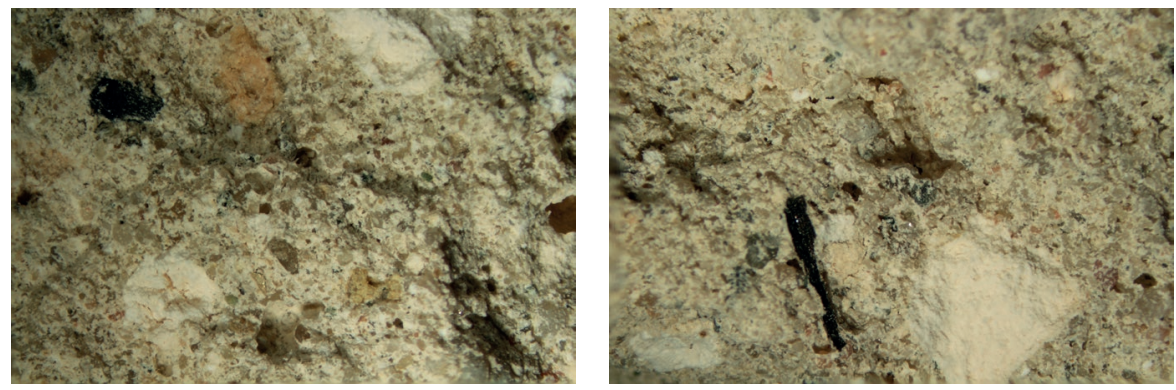

$\operatorname{Rdz} 10$

$\operatorname{Rdz} 11 \mathrm{z}$
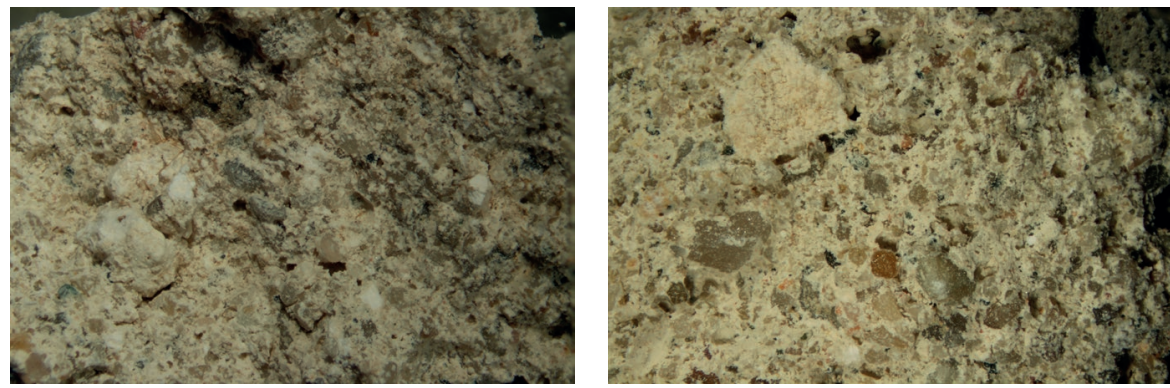

$\operatorname{Rdz} 12$

Fot. 3. Zamek w Radzyniu Chełmińskim. Próbki pobrane do badań. Przełamy próbek Rdz 6, Rdz 10, Rdz 11z, Rdz 12 w świetle odbitym. Fot. Karolina Witkowska

fibol, biotyt, granat, amfibol, cyrkon, rzadki zoizyt, biotyt oraz najrzadziej spotykany dysten (jedynie Rdz 12). Sporadycznie występują również węgiel drzewny (obecny we wszystkich próbkach: 0,3-2,0 $\mathrm{mm}$ ) i fragmenty cegły (Rdz 1, Rdz 2', Rdz 6, Rdz 8: 0,4-1,0 mm). Pod względem wyoblenia wypełniacz charakteryzuje się zmiennością. Osobniki większych rozmiarów są obtoczone i przede wszystkim półobtoczone do półostrokrawędzistych, natomiast mniejsze są zazwyczaj półostrokrawędziste, rzadziej półobtoczone, niekiedy ostrokrawędziste.

Bardzo interesujące jest spoiwo badanych zapraw. Zostało ono wykształcone przede wszystkim w postaci mikrokrystalicznej masy węglanowej o charakterze mikrytu z wyodrębnionymi grudkami wapna (Rdz 1, Rdz 2, Rdz 10 - do 8 mm, Rdz 2' - do 5 mm, Rdz 6 - do 4 mm, Rdz 8, Rdz 11z, Rdz 12 - do $3 \mathrm{~mm}$ ). Grudki te, o zróżnicowanym kształcie, są zbudowane z bezstrukturalnego mikrytu, w niektórych z nich są zauważalne drobne zrosty kryształów będące pozostałością po niezkalcynowanym surowcu skalnym, z którego przygotowano wapno palone. Zaobserwowane relikty świadczą o tym, że część kamienia wapiennego była wypalana w temperaturze poniżej $850^{\circ} \mathrm{C}$, w której następuje rozkład termiczny węglanu wapnia. 
Tabela1. Budowa mineralogiczna zapraw - skład ilościowy (wyniki podano w \% objętościowych bez porów) oraz sumaryczny udział procentowy ziaren reprezentujących poszczególne frakcje w budowie szkieletu ziarnowego

\begin{tabular}{|c|c|c|c|c|c|c|c|}
\hline $\begin{array}{c}\mathrm{Nr} \\
\text { próbki }\end{array}$ & $\begin{array}{c}\text { Spoiwo } \\
\text { [\%] }\end{array}$ & $\begin{array}{c}\text { Kwarc } \\
{[\%]}\end{array}$ & $\begin{array}{c}\text { Skalenie } \\
\text { [\%] }\end{array}$ & $\begin{array}{c}\text { Skały } \\
{[\%]}\end{array}$ & $\begin{array}{c}\text { Inne skł. } \\
\text { akceso- } \\
\text { ryczne } \\
{[\%]}\end{array}$ & $\begin{array}{c}\text { Frakcje: } \\
\text { pyłowa/ } \\
\text { piaszczysta/ } \\
\text { żwirowa } \\
\\
{[\%]}\end{array}$ & $\begin{array}{c}\text { Obecność faz } \\
\text { hydraulicznych } \\
\text { w spoiwie } \\
\text { węglanowym }\end{array}$ \\
\hline Rdz 1 & $\sim 41,0$ & $\sim 40,0$ & $\sim 3,5$ & $\sim 14,0$ & $\sim 1,5$ & $7,8 / 92,2 / 0,0$ & + \\
\hline Rdz 2' & $\sim 36,0$ & $\sim 44,0$ & $\sim 2,5$ & $\sim 16,5$ & $\sim 1,0$ & $8,4 / 90,9 / 0,7$ & + \\
\hline Rdz 6 & $\sim 50,0$ & $\sim 37,0$ & $\sim 3,0$ & $\sim 8,5$ & $\sim 1,5$ & $12,1 / 87,7 / 0,2$ & - \\
\hline Rdz 8 & $\sim 55,0$ & $\sim 33,0$ & $\sim 2,0$ & $\sim 6,5$ & $\sim 3,5$ & $16,3 / 83,7 / 0,0$ & + \\
\hline Rdz 10 & $\sim 53,5$ & $\sim 32,0$ & $\sim 3,0$ & $\sim 10,5$ & $\sim 1,0$ & $7,1 / 92,5 / 0,4$ & + \\
\hline $\mathrm{Rdz} 11 \mathrm{z}$ & $\sim 44,5$ & $\sim 39,0$ & $\sim 2,0$ & $\sim 12,5$ & $\sim 2,0$ & $10,1 / 88,3 / 1,6$ & + \\
\hline $\mathrm{Rdz} 12$ & $\sim 45,5$ & $\sim 36,0$ & $\sim 3,0$ & $\sim 13,5$ & $\sim 2,0$ & $8,9 / 90,8 / 0,3$ & + \\
\hline
\end{tabular}

Na podstawie analizy chemicznej stwierdzono, że stosunek części roztwarzalnej w $2 \mathrm{M} \mathrm{HCl}$ (spoiwo wapienne, ale również fragmenty kamienia wapiennego) do części nieroztwarzalnych w kwasie (nazywanych w uproszczeniu kruszywem) zawiera się między 1:1,5 a 1:1,8. Wyniki analizy termicznej wykazały zaś, że w zaprawach znajduje się od około $23 \%$ do $33 \%$ węglanu wapna, co po przeliczeniu daje stosunek węglanu wapna do pozostałości nieulegającej rozkładowi między 1:1,9 a 1:3,3, co pozostaje w znacznej dysproporcji do wyników analizy chemicznej (tab. 2). Analizie poddano również okruch wapna z zaprawy Rdz 10 o średnicy około 8 mm, w którym oznaczono $74 \%$ węglanu wapna. W żadnej z próbek nie zidentyfikowano wodorotlenku wapnia, co świadczy o wysokim stopniu karbonatyzacji spoiwa. Dodatkowo w zaprawie Rdz 8 odnotowano gips w ilości około 3,5\%. Obecność gipsu, niepotwierdzona w badaniu petrograficznym, jest najprawdopodobniej przypadkowa; minerał ten mógł też pochodzić z nawarstwień. Różnice w wynikach analizy termicznej i chemicznej wynikają zapewne z dużej niejednorodności próbek, a także 
z faktu, że część faz hydraulicznych w spoiwie uległa roztworzeniu w kwasie solnym. Ponadto analizując szlify cienkie stwierdzono, że zarówno w masie spoiwa, jak i wewnątrz niektórych skupień mikrytowych (grudek wapna) widoczne są drobne zrosty faz hydraulicznych ${ }^{24}$ (dotyczy to wszystkich zapraw poddawanych analizie petrograficznej, z wyjątkiem próbki Rdz 6).

Tabela2. Skład zapraw określony na podstawie analizy termicznej (DSC-TG) i analizy chemicznej wybranych próbek

\begin{tabular}{|c|c|c|c|c|c|}
\hline \multirow[b]{2}{*}{$\begin{array}{c}\mathrm{Nr} \\
\text { próbki }\end{array}$} & \multicolumn{3}{|c|}{ Analiza termiczna (DSC-TG) } & \multicolumn{2}{|c|}{ Analiza chemiczna } \\
\hline & $\begin{array}{c}\text { woda } \\
\text { higroskopijna } \\
\text { + woda } \\
\text { konstytucyjna } \\
{[\%]} \\
{\left[30-560^{\circ} \mathrm{C}\right]}\end{array}$ & $\begin{array}{c}\text { węglan } \\
\text { wapnia } \\
{[\%]} \\
{\left[>560^{\circ} \mathrm{C}\right]}\end{array}$ & $\begin{array}{c}\text { pozostałość } \\
\text { nieulegająca } \\
\text { rozkładowi } \\
\text { [\%] }\end{array}$ & $\begin{array}{c}\text { pozostałość } \\
\text { nieulegająca } \\
\text { roztworzeniu } \\
\text { w kwasie } \\
\text { [\%] }\end{array}$ & $\begin{array}{c}\text { stosunek } \\
\text { spoiwo } \\
\text { : kruszywo } \\
\text { (wagowo) }\end{array}$ \\
\hline $\mathrm{Rdz} 1$ & 1,88 & 33,54 & 64,58 & 62,62 & $\sim 1: 1,7$ \\
\hline $\mathrm{Rdz} 2$ & 2,15 & 27,70 & 70,15 & 62,47 & $\sim 1: 1,8$ \\
\hline Rdz 2' & 1,81 & 31,08 & 67,11 & 64,97 & $\sim 1: 1,8$ \\
\hline $\mathrm{Rdz} 6$ & 2,27 & 32,01 & 65,72 & 59,01 & $\sim 1: 1,5$ \\
\hline $\operatorname{Rdz} 8^{*}$ & 3,22 & 25,58 & 67,72 & 63,12 & $\sim 1: 1,7$ \\
\hline $\operatorname{Rdz} 10$ & 3,41 & 23,20 & 73,39 & 60,06 & $\sim 1: 1,7$ \\
\hline $\begin{array}{l}\text { Rdz } 10 \\
\text { grudka } \\
\text { wapna }\end{array}$ & 4,95 & 74,28 & 20,77 & - & - \\
\hline $\mathrm{Rdz} 11 \mathrm{z}$ & 2,67 & 27,98 & 69,36 & 60,05 & $\sim 1: 1,5$ \\
\hline $\mathrm{Rdz} 12$ & 4,06 & 26,61 & 69,33 & 64,39 & $\sim 1: 1,8$ \\
\hline
\end{tabular}

*Gips $\left[95-245^{\circ} \mathrm{C}\right]=3,48 \%$.

24 Bartz, “Raport”, 44. 
Na podstawie analizy termicznej obliczono procentowy ubytek masy badanych zapraw w zakresie temperatur pozwalającym na uzyskanie informacji o obecności faz hydraulicznych w spoiwie ${ }^{25}$ (tab. 3). Ubytek masy w zakresie do $120^{\circ} \mathrm{C}$ odpowiada za uwolnienie wody higroskopijnej, między 120 a $200^{\circ} \mathrm{C}$ za dehydratację gipsu, w przedziale $200-600^{\circ} \mathrm{C}$ zaś następuje uwolnienie wody konstytucyjnej w składnikach hydraulicznych, a rozkład termiczny kalcytu może rozpocząć się w temperaturze powyżej $600^{\circ} \mathrm{C}$. W tabeli 3 przedstawiono również stosunek masy $\mathrm{CO}_{2}\left(>600^{\circ} \mathrm{C}\right)$ do masy wody konstytucyjnej związanej przez składniki hydrauliczne, który informuje o charakterze spoiwa.

Tabela 3. Ubytek masy w zakresie temperatur pozwalającym na uzyskanie informacji o obecności faz hydraulicznych w spoiwie węglanowym określony na podstawie analizy termicznej (DSC-TG).

\begin{tabular}{|l|c|c|c|c|c|}
\hline \multirow{2}{*}{$\begin{array}{c}\mathrm{Nr} \\
\text { próbki }\end{array}$} & \multicolumn{4}{|c|}{ Ubytek masy w zakresie temperatur $\left({ }^{\circ} \mathrm{C}\right)[\%]$} & \multirow{2}{*}{} \\
\cline { 2 - 5 } & $<120$ & $120-200$ & $200-600$ & $>600$ & $\mathrm{CO}_{2} / \mathrm{H}_{2} \mathrm{O}$ \\
\hline $\mathrm{Rdz} 1$ & 0,26 & 0,21 & 1,62 & 13,89 & 8,57 \\
\hline $\mathrm{Rdz} 2$ & 0,45 & 0,28 & 1,84 & 13,00 & 7,03 \\
\hline $\mathrm{Rdz} 2$ & 0,32 & 0,19 & 1,47 & 16,88 & 11,48 \\
\hline Rdz 6 & 0,11 & 0,36 & 2,08 & 13,79 & 6,63 \\
\hline Rdz 8 & 0,32 & 0,41 & 3,37 & 11,68 & 3,46 \\
\hline Rdz 10 & 0,56 & 0,34 & 3,14 & 9,15 & 2,91 \\
\hline $\begin{array}{l}\text { Rdz 10 } \\
\text { grudka } \\
\text { wapna }\end{array}$ & 0,18 & 0,42 & 4,98 & 33,00 & 6,62 \\
\hline Rdz 11z & 0,47 & 0,22 & 2,36 & 11.92 & 5,05 \\
\hline Rdz 12 & 1,28 & 0,25 & 2,84 & 11,37 & 4,00 \\
\hline
\end{tabular}

25 Moropoulou, Bakolas i Bisbikou, “Characterisation of ancient”, 780-795; Moropoulou, Bakolas i Bisbikou, "Investigation of the technology”, 50-53. 
Posługując się klasyfikacją zaproponowaną przez Antonię Moropoulou i współautorów ${ }^{26}$, wśród badanych materiałów możemy wyróżnić dwie grupy:

- zaprawy wapienne, gdzie ubytek masy w temperaturze $200-600^{\circ} \mathrm{C}$ jest niższy niż $3 \%$, a stosunek $\mathrm{CO}_{2} / \mathrm{H}_{2} \mathrm{O}$ wynosi ponad 6,5 ,

- zaprawy reprezentujące spoiwo wapienne o cechach hydraulicznych, gdzie ubytek masy w temperaturze $200-600^{\circ} \mathrm{C}$ zawiera się w przedziale 3-6\%,a stosunek $\mathrm{CO}_{2} / \mathrm{H}_{2} \mathrm{O}$ między 3,5 a 6,5.

Żadnej z analizowanych próbek nie można natomiast określić jako zaprawy hydraulicznej, gdzie ubytek masy w temperaturze $200-600^{\circ} \mathrm{C}$ wynosi ponad $10 \%$, a stosunek $\mathrm{CO}_{2} / \mathrm{H}_{2} \mathrm{O}$ poniżej 3,5.

Przeprowadzona analiza przyniosła następujące wyniki: Próbki Rdz 1, Rdz 2, Rdz 2', Rdz 6 są zaprawą typowo wapienną. Próbki Rdz 8 i Rdz 10 wykazują cechy hydrauliczne. Szczególnie silnie cechy te wykazuje grudka wapna pobrana z zaprawy Rdz 10, o prawie 5-proc. ubytku masy w zakresie temperatur, w których następuje uwolnienie wody konstytucyjnej w składnikach hydraulicznych, oraz stosunku $\mathrm{CO}_{2} / \mathrm{H}_{2} \mathrm{O}$ nieznacznie przekraczającym 6,5. Próbki Rdz 11z i Rdz 12 w procentowej utracie masy w temperaturze $200-600^{\circ} \mathrm{C}$ zbliżają się do zapraw wapiennych, natomiast w stosunku $\mathrm{CO}_{2} / \mathrm{H}_{2} \mathrm{O}$ do zaprawo cechach hydraulicznych.

Zaobserwowane właściwości hydrauliczne badanych zapraw mogą być spowodowane wypałem wapna ze skał węglanowych zawierających podrzędne ilości minerałów ilastych. Pojawienie się faz hydraulicznych w zaprawach wapiennych niektórzy autorzy łączą również z technologią tzw. gorących zapraw. Dowiedziono, że wysoka temperatura, która powstaje podczas gaszenia wapna wymieszanego z naturalnym (niepłukanym) piaskiem, może spowodować przemianę zawartych w kruszywie minerałów ilastych w przymieszki hydrauliczne ${ }^{27}$. Gaszenie wapna palonego jako reakcja egzotermiczna (temperatura powyżej $300^{\circ} \mathrm{C}$ ) w silnie alkalicznym środowisku umożliwia przemianę minerałów ilastych(aktywacja krzemionki) ${ }^{28}$, które wraz z wodorotlenkiem wapnia tworzą krzemiany i gliniany wapniowe. Ostateczne okre-

26 Por. przyp. 21.

27 Bernhard Middendorf, Karin Kraus i Christina Ott, "Influence of the Fines in Natural Sands as Pozzolanic Components on the Interpretation of the Acid-soluble Silica Content of Historic Lime Mortars”, w Proceedings of the International Building Lime Symposium, red. Rochelle C. Jaffe (Orlando - Florida: National Lime Association, 2005), 1-11.

28 Antonia Moropoulou et al., “Technology and Behavior of Rubble Masonry Mortars”, Construction and Building Materials 11, no. 2 (1997): 128. 
ślenie przyczyn występowania faz hydraulicznych w badanych zaprawach wapiennych wymaga dalszych, pogłębionych badań.

\section{Cegły}

Na podstawie analizy makroskopowej i mikroskopowej, a także badań petrograficznych, stwierdzono, że pod względem koloru próbki podzielić można na dwie grupy: cegły o kolorze pomarańczowobrunatnym (Rdz 3, Rdz 4, $\mathrm{Rdz} 7, \mathrm{Rdz} 9$ ) i brunatnoszarym do brunatnoczarnego (Rdz 5, Rdz 11c) reprezentujące cegły zendrówki. Powierzchnia przełamu cegieł pierwszej grupy jest matowa, natomiast druga grupa charakteryzuje się szklistym połyskiem (fot. 4). Wszystkie próbki mają teksturę bezładną i zbliżony charakter spoiwa (głównie afanitowe, miejscami mikrokrystaliczne).
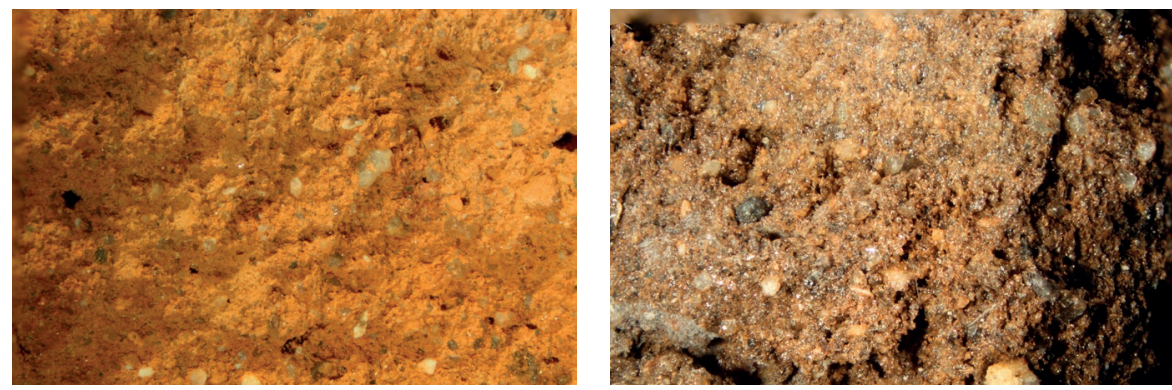

Fot. 4. Zamek w Radzyniu Chełmińskim. Próbki pobrane do badań. Przełamy próbek Rdz 4 i Rdz 11c w świetle odbitym. Fot. Karolina Witkowska

Analiza petrograficzna ujawniła, że badane cegły, choć różnią się makroskopowo zabarwieniem, w obrazie mikroskopowym nie wykazują już tak dużego zróżnicowania (tab. 4$)^{29}$. Zauważono, że materiał okruchowy budujący szkielet ziarnowy cegieł ma skład zbliżony do szkieletu analizowanych równolegle zapraw (por. tab. 4). Podstawowym jego komponentem są ziarna kwarcu, obok nich spotyka się skalenie i fragmenty skał (przede wszystkim granitoidy, ale także skały krzemionkowe). Szkielet ziarnowy uzupełniają składniki akcesoryczne, wśród których najczęściej występują czerwone, owalne drobnokrystaliczne skupienia (przypuszczalnie termicznie przeobrażony glaukonit), ziarna minerałów nieprzezroczystych, oksyhornblenda, muskowit,

29 Bartz, "Raport”, 37-38, 44-47. 
epidot i rutyl. Rzadziej dały się zaobserwować cyrkon, zoizyt, granat i hornblenda zwyczajna (tylko zendrówki), a sporadycznie biotyt. Cegły pomarańczowobrunatne od szarobrunatnych różni charakter masy metailastej. Jasna ceramika charakteryzuje się dominującym spoiwem afanitowym, częściowo mikrokrystalicznym, z widocznymi zachowanymi minerałami ilastymi (najwięcej reliktów pierwotnych minerałów ilastych zaobserwowano w próbce Rdz 4). Ciemno zabarwione cegły mają spoiwo nieprzezroczyste, całkowicie afanitowe, a budujące je składniki są niewidoczne, bez zachowanych jakichkolwiek reliktów minerałów ilastych.

Tabela 4. Budowa mineralogiczna cegieł - skład ilościowy (wyniki podano w \% objętościowych bez porów) oraz sumaryczny udział procentowy ziaren reprezentujących poszczególne frakcje w budowie szkieletu ziarnowego

\begin{tabular}{|l|c|c|c|c|c|c|}
\hline $\begin{array}{c}\mathrm{Nr} \\
\text { próbki }\end{array}$ & Spoiwo & Kwarc & Skalenie & Skały & $\begin{array}{c}\text { Inne skł. } \\
\text { akceso- } \\
\text { ryczne }\end{array}$ & $\begin{array}{c}\text { Frakcje: } \\
\text { pyłowal } \\
\text { piaszczysta/ } \\
\text { żwirowa }\end{array}$ \\
\hline Rdz3 & $\sim 50,0 \%$ & $\sim 35,5 \%$ & $\sim 5,0 \%$ & $\sim 8,0 \%$ & $\sim 2,0 \%$ & $71,0 / 29,0 / 0,0$ \\
\hline Rdz4 & $\sim 54,5 \%$ & $\sim 34,0 \%$ & $\sim 3,5 \%$ & $\sim 6,5 \%$ & $\sim 1,5 \%$ & $70,2 / 29,8 / 0,0$ \\
\hline $\begin{array}{l}\text { Rdz5 } \\
\text { zendrówka }\end{array}$ & $\sim 60,5 \%$ & $\sim 29,0 \%$ & $\sim 3,0 \%$ & $\sim 6,0 \%$ & $\sim 1,5 \%$ & $66,7 / 33,3 / 0,0$ \\
\hline Rdz7 & $\sim 55,0 \%$ & $\sim 33,0 \%$ & $\sim 3,5 \%$ & $\sim 6,5 \%$ & $\sim 2,0 \%$ & $74,7 / 25,3 / 0,0$ \\
\hline Rdz9 & $\sim 52,0 \%$ & $\sim 35,0 \%$ & $\sim 4,0 \%$ & $\sim 7,5 \%$ & $\sim 1,5 \%$ & $76,8 / 23,2 / 0,0$ \\
\hline $\begin{array}{l}\text { Rdz11c } \\
\text { zendrówka }\end{array}$ & $\sim 47,0 \%$ & $\sim 43,0 \%$ & $\sim 4,0 \%$ & $\sim 5,0 \%$ & $\sim 1,0 \%$ & $62,4 / 37,6 / 0,0$ \\
\hline
\end{tabular}

We wszystkich badanych próbkach w szkielecie ziarnowym dominują zdecydowanie osobniki reprezentujące frakcję pyłową. Ich ilość zmienia się w zakresie 62,4-76,8\% (tab. 4.). W wyniku analizy makroskopowej w badanych cegłach stwierdzono ponadto występowanie nieobecnej w szlifach 
cienkich frakcji żwirowej. Największe osobniki zaobserwowano w próbkach Rdz 4 i Rdz 7 (9 mm), w pozostałych kruszywo nie przekracza $6 \mathrm{~mm}$. We wszystkich analizowanych cegłach ziarna są zazwyczaj półostrokrawędziste do ostrokrawędzistych, rzadziej zaś półobtoczone (głównie wśród ziaren o większych rozmiarach). Przewaga występowania słabo wyoblonych ziaren zdaje się potwierdzać przypuszczenie, że surowiec do produkcji radzyńskiej ceramiki budowlanej pochodził ze złóż gliny zwałowej ${ }^{30}$.Uziarnienie składników okruchowych i kształt ziaren szkieletu badanych cegieł nie wykazują większego zróżnicowania. Obserwowane różnice są relatywnie niewielkie i nie pozwalają na wyodrębnienie wśród badanych próbek jakiejkolwiek grupy cegieł. Cechująca wszystkie badane cegły bezładna struktura, duża jednorodność spoiwa, równomiernie rozproszony szkielet ziarnowy oraz brak wtrąceń i większych spękań świadczą o dobrym wymieszaniu składników masy ceglarskiej i prawidłowo przeprowadzonym procesie produkcji ceramiki.

\section{Wnioski}

Wyniki przeprowadzonych badań składają się na bliższą charakterystykę materiałów budowlanych, z których zbudowano zamek w Radzyniu Chełmińskim, czyli cegieł formatowych i zapraw murarskich. Stwierdzono, że w porównaniu do dotychczas analizowanych próbek pochodzących z zamków krzyżackich w Malborku i Toruniu ${ }^{31}$ - radzyńskie materiały są stosunkowo jednorodne. Generalnie ceramikę ze wszystkich wymienionych obiektów cechuje duża jednorodność spoiwa i równomiernie rozproszony szkielet ziarnowy, w którego skład wchodzi głównie kwarc z dodatkiem skaleni i fragmentów skał. Analiza zapraw wykazała natomiast, że zaprawy malborskie i toruńskie, mimo wielu podobieństw w składzie, wykazują znaczące różnice w proporcjach poszczególnych składników: w zaprawach z zamku w Malborku stosunek spoiwa do kruszywa zawiera się między 1:1,7 a 1:3,5, w zaprawach z zamku w Toruniu zaś między 1:1,7a 1:3,1. Na tym tle radzyńskie zaprawy charakteryzują się wysoką zawartością spoiwa w stosunku do kruszywa - w proporcji od 1:1,5 do 1:1,8.

30 Sara Pavia i Susana Caro, "Petrographic Microscope Investigation of Mortar and Ceramic Technologies for Conservation of the Building Heritage", Proc. SPIE 6618, O3A: Optics for Arts, Architecture, and Archaeology 66181H (2007): 9, Dostęp 16 maja 2015, doi:10.1117/12.726186.

31 Witkowska i Łukaszewicz, „Comparative Studies”, 621-628. 
Ponadto analiza petrograficzna wykazała, że składniki okruchowe szkieletu ziarnowego cegieł i zapraw z zamku w Radzyniu Chełmińskim mają zbliżony skład. Podobieństwo to może sugerować, że kruszywo użyte jako wypełniacz w zaprawach i dodatek schudzający masę ceglarską pochodzi z tego samego lub zbliżonego źródła, potwierdzając tezę o lokalnym pochodzeniu surowca. Jak stwierdzono, prawie wszystkie zaprawy (z wyjątkiem próbki Rdz 6) zawierają spoiwo wapienne o udziale frakcji hydraulicznych. Identyfikację faz hydraulicznych w zaprawach potwierdzono częściowo za pomocą analizy termicznej, uznając, że jest to metoda umożliwiająca weryfikację ich obecności w toku dalszych badań. Należy podkreślić, że scharakteryzowane w artykule zaprawy - o cechach wyjątkowych na terenie państwa zakonu krzyżackiego - mogą być kluczem do wyjaśnienia przyczyn stosunkowo dobrego stanu zachowania ruin radzyńskiego zamku. Omówione badania powinny zostać uzupełnione przez zastosowanie dyfraktometrii rentgenowskiej (XRD) i spektroskopii w podczerwieni (FTIR).

\section{Bibliografia}

Architektura gotycka w Polsce, t. 2, red. Teresa Mroczko i Marian Arszyński. Warszawa: Instytut Sztuki PAN, 1995.

Arszyński, Marian.“Budownictwo”. W Zakon krzyżacki i jego państwo w Prusach: wybór tekstów źródłowych, red. Andrzej Radzimiński, 123-144. Toruń: Wydawnictwo Uniwersytetu Mikołaja Kopernika, 2005.

Arszyński, Marian. Budownictwo warowne zakonu krzyżackiego w Prusach (1230-1454).

Torun: Wydawnictwo Uniwersytetu Mikołaja Kopernika, 1995.

Arszyński, Marian. Organizacja i technika średniowiecznego budownictwa ceglanego w Prusach w kontekście europejskim. Malbork: Muzeum Zamkowe w Malborku, 2016.

Arszyński, Marian. "Problematyka techniczna budownictwa średniowiecznego Polski północnej na przełomie XIV i XV w.” Biuletyn Informacyjny PKZ 8 (1968): 95-122.

Arszyński, Marian. “Stosunki między zakonem krzyżackim a społeczeństwem w świetle rozważań nad organizacją budowy kościołów parafialnych w Prusach”. W Zakon krzyżacki a społeczeństwo państwa w Prusach: zbiór studiów, red. Zenon H. Nowak, 165-184. Toruń: Towarzystwo Naukowe, 1995.

Arszyński, Marian. „Technika i organizacja budownictwa ceglanego w Prusach w końcu XIV w. i poł. XV w.” Studia z Dziejów Rzemiosła i Przemysłu 9 (1970): 7-139.

Arszyński, Marian. "Warsztat budowlany w Prusach około 1400”. Biuletyn Historii Sztuki 29, nr 4 (1967): 582-583.

Arszyński, Marian. “Z badań nad zamkiem pokrzyżackim w Radzynie”. Rocznik Grudziądzki 2 (1961): 39-77. 
Bartz, Wojciech. “Raport z badań mineralogiczno-petrograficznych: zaprawy i cegły z zamków w Toruniu i Radzyniu Chełmińskim”. Raport z badań, maszynopis w posiadaniu autora opracowania i autorki tekstu, Wrocław 2016.

Brochwicz, Zbigniew. “Zaprawa wapienna jako tworzywo elementów architektonicznych na przykładzie służek w kaplicy zamkowej w Radzyniu Chełmińskim”. AUNC. Zabytkoznawstwo i Konserwatorstwo 4 (1971): 127-139.

Herrmann, Christofer. Mittelalterliche Architektur im Preussenland: Untersuchungen zur Frage der Kunstlandschaft und -geographie. Petersberg, Olsztyn: Michael Imhof Verlag, 2007.

Middendorf, Bernhard, Karin Kraus, i Christina Ott."Influence of the Fines in Natural Sands as Pozzolanic Components on the Interpretation of the Acid-soluble Silica Content of Historic Lime Mortars”. W Proceedings of the International Building Lime Symposium, red. Rochelle C. Jaffe, 1-11. Orlando - Florida: National Lime Association, 2005.

Moropoulou, Antonia, Asterios Bakolas, i Katerina Bisbikou.“Characterization of Ancient, Byzantine and Later Historic Mortars by Thermal and X-ray Diffraction Techniques”. Thermochimica Acta 269/270 (1995): 779-795.

Moropoulou, Antonia, Asterios Bakolas, i Katerina Bisbikou. "Investigation of the Technology of Historic Mortars”. Journal of Cultural Heritage 1, no. 1(2000): 45-58.

Moropoulou, Antonia, Guido Biscontin, Asterios Bakolas, i Katerina Bisbikou. "Technology and Behavior of Rubble Masonry Mortars”. Construction and Building Materials 11, no. 2 (1997): 119-129.

Pavia, Sara, i Susana Caro."Petrographic Microscope Investigation of Mortar and Ceramic Technologies for Conservation of the Building Heritage”. Proc. SPIE 6618, O3A: Optics for Arts, Architecture, and Archaeology 66181H (2007): 1-12. Dostęp 16 maja 2015. doi:10.1117/12.726186.

Skibiński, Sławomir. "Przyczyny niszczenia cegieł zabytkowych murów obronnych Torunia oraz zamku krzyżackiego w Toruniu”. W Naukowe podstawy ochrony i konserwacji dzieł sztuki oraz zabytków kultury materialnej, red. Alicja Strzelczyk i Sławomir Skibiński, 187-198. Toruń: Wydawnictwo Uniwersytetu Mikołaja Kopernika, 1998.

Sławiński, Ireneusz. “Z badań nad zamkami w Golubiu, Radzyniu i Brodnicy”. W Komunikaty na sesję naukową poświęcona dziełom sztuki Pomorza zorganizowaną w 500-lecie pokoju toruńskiego, 50-58. Toruń: s.n., 1966.

Sobkowiak, Dorota, i Elżbieta Orłowska. “Analiza źródeł architektonicznych. Wyniki badań składu zapraw”. W Zamek w Grudziądzu w świetle badań archeologiczno-architektonicznych: studia i materiały, red. Marcin Wiewióra, 157-158.Toruń: Instytut Archeologii Uniwersytetu Mikołaja Kopernika; Grudziądz: Urząd Miejski, 2012.

Tandecki, Janusz. "Podziały administracyjne państwa zakonnego w Prusach”. W Zakon krzyżacki w Prusach i Inflantach. Podziały administracyjne i kościelne w XIII-XIV wie$k u$, red. Roman Czaja, Andrzej Radzimiński, 29-53. Toruń: Wydawnictwo Naukowe Uniwersytetu Mikołaja Kopernika, 2013. 
Torbus, Tomasz. Die Konventsburgen im Deutschordensland Preußen. München: R. Oldenbourg, 1998.

Torbus, Tomasz. Zamki konwentualne państwa krzyżackiego w Prusach. Gdańsk: Fundacja Terytoria Książki: Słowo/Obraz Terytoria, 2014.

Wasik, Bogusz. Budownictwo zamkowe ziemi chełmińskiej (od XIII do XV wieku). Toruń: Wydawnictwo Naukowe Uniwersytetu Mikołaja Kopernika, 2016.

Wasik, Bogusz. "Początki krzyżackich zamków na ziemi chełmińskiej. Pierwsze warownie i obiekty murowane”. Archaeologia Historica Polona, 24 (2016): 233-260.

Wasik, Bogusz."Zamek w Radzyniu Chełmińskim: technika i etapy budowy siedziby krzyżackich komturów i konwentu”. Ochrona Zabytków 68, nr 1 (2015): 165-178.

Witkowska, Karolina, i Jadwiga W. Łukaszewicz. "Comparative Studies on Masonry Bricks and Bedding Mortars of the Fortress Masonry of the Teutonic Order State in Prussia: Malbork, Toruń and Radzyń Chełmiński Castles”.W Science and Art: A Future for Stone: Proceedings of the 13th International Congress on the Deterioration and Conservation of Stone, t. 1, red. John J. Hughes i Torsten Howind, 621-629. Paisley: University of the West of Scotland Press, 2016.

Zamek biskupów chełmińskich $w$ Wąbrzeźnie $w$ świetle badań archeologiczno-architektonicznych: studia i materiały, red. Marcin Wiewióra. Toruń: Wydawnictwo Naukowe Uniwersytetu Mikołaja Kopernika, 2014.

Zamek w Grudziądzu w świetle badań archeologiczno-architektonicznych: studia i materiały, red. Marcin Wiewióra. Toruń: Instytut Archeologii Uniwersytetu Mikołaja Kopernika; Grudziądz: Urząd Miejski, 2012.

\section{Materiały internetowe}

Internetowy Atlas Województwa Kujawsko-Pomorskiego: Mapa geologiczna utworów powierzchniowych 1:500 000. Dostęp 5 kwietnia 2017, http://atlas.kujawsko-pomorskie.pl/maps/app/map\# 